\title{
PERKEMBANGAN BIBIT AREN (Arenga pinnata Merr) YANG DIKULTUR PADA MEDIA MS DAN WPM
}

\section{DEVELOPMENT OF Arenga pinnata Merr SEEDLINGS CULTURED ON MS AND WPM MEDIUM}

\author{
Made Ria Defiani, Ida Ayu Astarini, Eniek Kriswiyanti, Ni Luh Suriani \\ Program Studi Biologi FMIPA, Universitas Udayana, Bali, Indonesia \\ Email:maderia@unud.ac.id
}

\begin{abstract}
ABSTRAK
Tanaman aren tergolong dalam keluarga Palmae. Secara ekonomis, pohon aren sangat bermanfaat dimana daunnya digunakan untuk keperluan upacara adat di Bali, nira dapat diproses untuk minuman khas Bali yang dikenal dengan nama "tuak", dan buahnya untuk penganan seperti kolak dan es campur. Perbanyakan tanaman aren secara alami sulit dilakukan karena benih aren memiliki masa dormansi yang panjang. Alternatif perbanyakan dapat dilakukan dengan teknik kultur jaringan. Media kultur (MS atau WPM) dapat ditambah hormon auksin dan sitokinin untuk mempercepat induksi tunas atau akar. Tujuan penelitian adalah menentukan media kultur yang cocok untuk pertumbuhan apokol secara aseptik. Hormon auksin yaitu 2.4-D 4 ppm ditambahkan ke media untuk induksi kalus, sedangkan IBA 1.5 ppm diberikan untuk induksi akar. Hormon BAP $1.5 \mathrm{ppm}$ yang tergolong sitokinin ditambahkan untuk menginduksi tunas. Bahan tanaman menggunakan apokol aren dengan 10 ulangan. Parameter yang diamati adalah kalus yang terbentuk dan pertumbuhan eksplan. Hasil penelitian menunjukkan pada umur 6 minggu setelah kultur eksplan berupa apokol, dapat terlihat massa kalus pada media WPM dengan tambahan 2.4$\mathrm{D}$, sedangkan tambahan IBA dan BAP tidak menunjukkan pertumbuhan dari eksplan apokol. Pengamatan anatomi menunjukkan eksplan apokol menunjukkan struktur perkembangan yang sama untuk semua perlakuan, dimana diferensiasi baru dimulai setelah fase globuler.
\end{abstract}

Kata kunci: 2,4-D, NAA, BAP, kalus, aren

\section{ABSTRACT}

Arenga palm (Arenga pinnata) is one species from Palmae family. Economically, the palm is suitable for home industry, such as Balinese offering which use parts of young leaf, sap can be used as special local genius sweet drink from Bali, fruits are boiled that can be mixed with sugar for healthy ice. Arenga palm can be propagated aseptically using tissue culture technique. Culture media may varied between MS and WPM with or without adding hormone. Auxin can be added as 2.4-D ( $4 \mathrm{ppm}$ ) to induce callus. IBA and BAP with concentration $1.5 \mathrm{ppm}$ respectively also added to induce multiplication of shoots or roots. Apocol was used as explant. Each treatment had 10 replications. Callus formation and growth of explants were observed. Six weeks after cultured, callus growth observed only at WPM media that enriched with 2,4-D. The others treatment show the explant had same growth with early differentiation while analysed anatomically under microscope.

Keywords: 2.4-D, NAA, BAP, callus, arenga palm

\section{PENDAHULUAN}

Aren merupakan tanaman tahunan yang menghasilkan banyak produk, misalnya untuk penganan kolang kaling untuk campuran es dan kolak, bagian ijuk untuk atap bangunan, sapu dan sikat, air nira untuk 
gula aren dan nata de pinna (Ruslan et al., 2018). Menurut Brownleader dan Dey (1997) biomassa tanaman dapat mensuplai hingga $15 \%$ dari kebutuhan energi melalui konversi lignoselulosa menjadi alkohol. Saat ini, aren juga dimanfaatkan sebagai salah satu sumber bioetanol (Effendi, 2010; Pamungkas dan Haryjanto, 2016). Pemanfaatan tanaman aren sudah berlangsung lama, namun tanaman aren lambat menjadi komoditi agribisnis karena masih mengandalkan tanaman yang tumbuh secara alami di habitatnya.

Konservasi sumberdaya genetik diperlukan untuk mempertahankan potensi sumber daya alam hayati. Perbanyakan tanaman secara konvensional akan memerlukan waktu hampir 10 tahun untuk memperoleh varietas baru walaupun kadang sifat genetik yang diinginkan belum diperoleh (Brownleader dan Dey, 1997). Oleh karena itu, upaya pelestarian dan percepatan tanaman aren menjadi komoditi agribisnis perlu dilakukan, misalnya suplai bibit yang unggul dan bermutu dengan memanfaatkan teknik kultur jaringan tanaman (Dewi, 2017).

Pengumpulan dan pemilihan biji aren sebagai sumber benih dapat dilakukan dengan memperhatikan kondisi pohon aren yang pertumbuhannya sehat dan berdaun lebat. Buah aren sudah masak memiliki ukuran diameter minimal $4 \mathrm{~cm}$, berwarna kuning kecoklatan dengan daging buah lunak dan kulit buah halus. Seleksi biji yang akan digunakan untuk perbanyakan tanaman dilakukan berdasarkan kriteria, misalnya ukuran biji yang relatif besar dengan warna hitam kecoklatan, permukaan halus (tidak keriput) dan biji dalam keadaan sehat/tidak berpenyakit.

Biji aren yang sulit berkecambah dapat menghambat ketersediaan bibit aren. Pada awal perkecambahan biji aren ditandai dengan munculnya apokol yang akan berkembang lebih lanjut menjadi akar. Apokol yang tumbuh pada tahap awal perkembangan kecambah memerlukan waktu dan kondisi tempat tumbuh yang sesuai agar cepat membentuk akar dan tunas. Teknik perbanyakan tanaman dengan memanfaatkan teknik kultur jaringan dapat digunakan untuk memperbanyak tanaman aren. Apokol dapat digunakan sebagai eksplan dalam perbanyakan in vitro karena sifat totipotensi sel tanaman.

Beberapa penelitian tentang aren sudah dilakukan baik secara in vivo maupun in vitro. Arsyad (2013) melakukan penyelamatan embrio dan produksi bibit aren melalui kultur jaringan. Multiplikasi embrio dilakukan oleh Wahyudi et al. (2013) dengan penambahan hormon Kinetin dan NAA. Kartina et al. (2011) menggunakan media MS dan hormon IBA untuk merangsang pertumbuhan akar secara aseptik. Dewi (2017) melakukan penelitian tentang perbanyakan aren secara in vivo dan in vitro dengan hasil pertumbuhan apokol dari biji yang ditanam. Apokol hasil dari kultur tersebut dapat digunakan sebagai sumber eksplan dalam upaya untuk mempercepat perolehan bibit aren dalam jumlah banyak.

Media dalam kultur jaringan memiliki komposisi yang berbeda. Media MS merupakan media yang paling banyak digunakan untuk berbagai spesies tanaman. Media WPM merupakan media khusus 
untuk tanaman berkayu yang memiliki konsentrasi ion yang lebih rendah dari media MS. Pada umumnya, media dasar tersebut dilengkapi dengan hormon. Penambahan hormon sintetik dapat merangsang pertumbuhan akar (golongan auksin) dan tunas (golongan sitokinin) dari eksplan.

Penelitian bertujuan menentukan media kultur yang cocok untuk menginduksi pertumbuhan apokol aren secara in vitro dengan menggunakan media Murashige and Skoog (MS) dan Woody Plant Medium (WPM).

\section{METODE PENELITIAN}

\section{Bahan penelitian}

Apokol aren berumur 12 bulan dalam kultur digunakan sebagai eksplan. Media yang digunakan adalah MS (Wahyudi et al., 2013) dan WPM (Ajijah, 2016), hormon 2,4D, IBA dan BAP.

Persiapan media tanam dan penanaman apokol

Media MS dan WPM yang digunakan adalah media instan yang sudah dilengkapi dengan unsur hara makro, mikro, vitamin dan asam amino. Ada tiga tahap pembuatan media setelah melihat keberhasilan perolehan kultur yang terbebas dari kontaminasi jamur, yaitu (1) Pada tahap pertama tidak dilakukan penambahan hormon auksin dan sitokinin. Pembuatan media MS per liter memerlukan penambahan gula $30 \mathrm{~g}$, agar $8 \mathrm{~g}$ dan media MS 4.4 g. Pembuatan media WPM per liter memerlukan penambahan gula $30 \mathrm{~g}$, agar $8 \mathrm{~g}$ dan media WPM $1.2 \mathrm{~g}$ tanpa penambahan hormon auksin maupun sitokinin; (2) Pada tahap kedua, hormon 2.4-D dengan konsentrasi 4 ppm ditambahkan ke media MS dan WPM; (3) Pada tahap ketiga, hormon BAP 1.5 ppm dan IBA 1.5 ppm ditambahkan ke media MS dan WPM.

Ketiga tahap pembuatan media tersebut dilarutkan dalam $1 \mathrm{~L}$ akuades dan diukur $\mathrm{pH}$ berkisar antara $5.5-6$. Tepung agar ditambahkan untuk membuat media padat serta arang aktif $0.5 \mathrm{~g} / \mathrm{L}$. Media diautoklaf selama 20 menit agar steril.

Percobaan ini menggunakan Rancangan Acak Lengkap (RAL) dengan satu faktor yaitu perlakuan media. Perlakuan media MS dan WPM diulang sebanyak 10 ulangan dengan 1 eksplan apokol per botol. Apokol disubkultur dengan ukuran $0.5-1 \mathrm{~cm}$. Kultur aren disimpan dalam ruangan dengan suhu $22^{\circ} \mathrm{C}$ dan pencahayaan 18 jam terang dan 6 jam gelap.

\section{Persiapan preparat untuk pengamatan anatomi}

Eksplan kalus yang lunak diberi perlakuan fiksasi dengan menggunakan kombinasi antara formalin:AAG:alkohol absolut (FAA) dengan komposisi 1:1:9 selama 24 jam. Selanjutnya kalus dicuci dengan alkohol 70\% selama 10-20 menit dilanjutkan dengan alkohol 96\% selama 1020 menit sebanyak dua kali pencucian. Kalus tersebut diberi perlakuan dengan alkohol dan xilol (3:1) selama 10-20 menit lalu dilanjutkan dengan perlakuan parafin:xilol (4:1) selama 24 jam, kemudian dibuat blok. Pembuatan preparat dilakukan di BBVET (Balai Besar Veteriner) di Denpasar.

\section{Pengamatan}

Variabel yang diamati adalah tingkat kontaminasi eksplan (pada 1-3 MST), eksplan yang menumbuhkan kalus, atau akar atau tunas, yang diamati sampai minggu ke12. 
SIMBIOSIS VIII (1 ):34-40

Program Studi Biologi FMIPA UNUD

\section{HASIL DAN PEMBAHASAN}

Hasil

Subkultur apokol ke dalam media MS dan WPM tanpa penambahan hormon

Berdasarkan hasil pengamatan sejak awal kultur apokol dapat dilihat bahwa subkultur apokol pada media MS dan WPM tanpa penambahan hormon terkontaminasi dengan jamur. Jamur berasal dari kultur apokol yang sudah berumur hampir 12 bulan. Oleh karena itu, pada tahap selanjutnya dilakukan sterilisasi terhadap apokol yang disubkultur dengan menggunakan 5\% Bayclin untuk membersihkan sumber kontaminan.
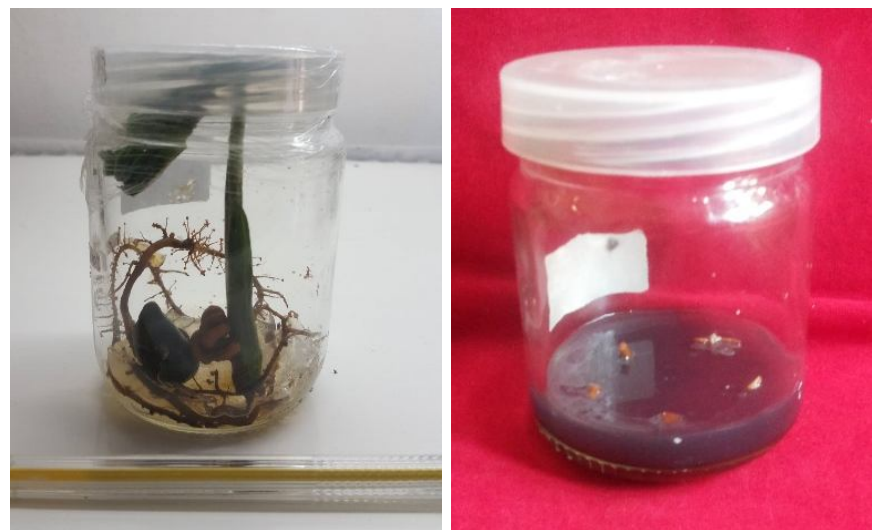

Gambar 1. Sumber eksplan apokol umur 12 bulan yang disubkultur (kiri) dan hasil subkultur 3 HST (kanan)

Subkultur apokol ke dalam media MS dan WPM dengan penambahan 2.4-D (auksin)

Apokol hasil perbanyakan kultur jaringan disterilisasi permukaan dan selanjutnya disubkultur ke media baru. Penambahan hormon 2.4-D dilakukan untuk menginduksi kalus apokol pada media MS dan WPM. Hasil yang diperoleh adalah kalus yang muncul di media WPM walau hanya satu botol kultur (Gambar 2).
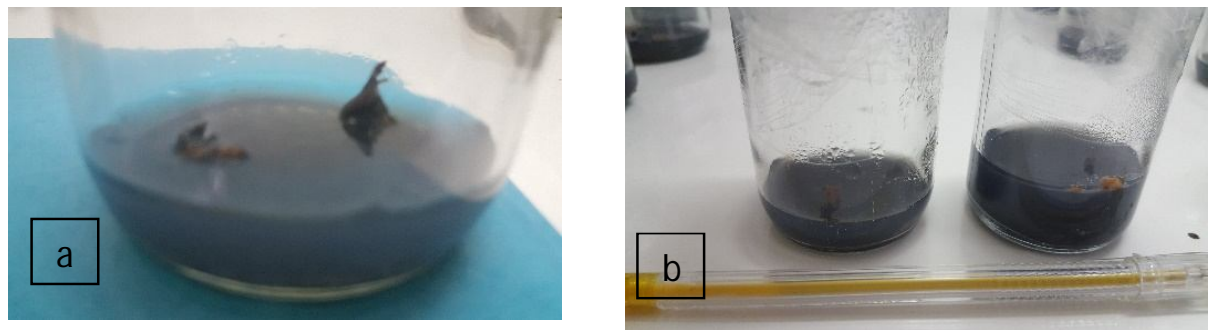

Gambar 2. a) Kalus pada kultur apokol umur 9 MST, b) apokol pada media induksi kalus umur 2 MST

Subkultur apokol ke media MS dan WPM dengan penambahan hormon BAP dan IBA
Apokol yang telah tumbuh kalus (Gambar 2.a), disubkultur dengan menggunakan media MS dan WPM dengan menambahkan BAP $1.5 \mathrm{ppm}$ dan IBA 1.5 
ppm. Pada umur kultur 14 HST hasil subkultur masih bersih dari kontaminasi (Gambar 3) namun belum ada respon

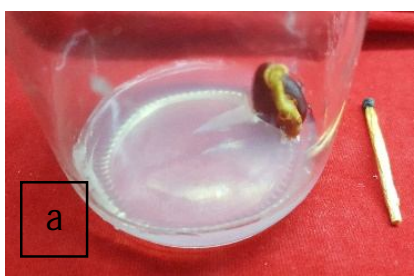

terhadap penambahan hormon ke media tanam.

Gambar 3. a) Sumber eksplan apokol; b) eksplan apokol umur 2 MST pada media WPM dan c) eksplan apokol umur 2 MST pada media MS yang diperkaya dengan hormon IBA dan BAP.

\section{Pengamatan anatomi eksplan}

Saat eksplan berumur 12 minggu, berdasarkan hasil anatomi eksplan dapat diketahui bahwa sudah terjadi pertumbuhan pada eksplan yang ditumbuhkan pada media WPM dengan penambahan hormon 2.4-D
(Gambar 4) dan media MS dengan penambahan hormon BAP 1.5 ppm dan IBA 1.5 ppm (Gambar 5). Tahap globuler sudah terlewati dan eksplan mulai pada fase diferensiasi sel.

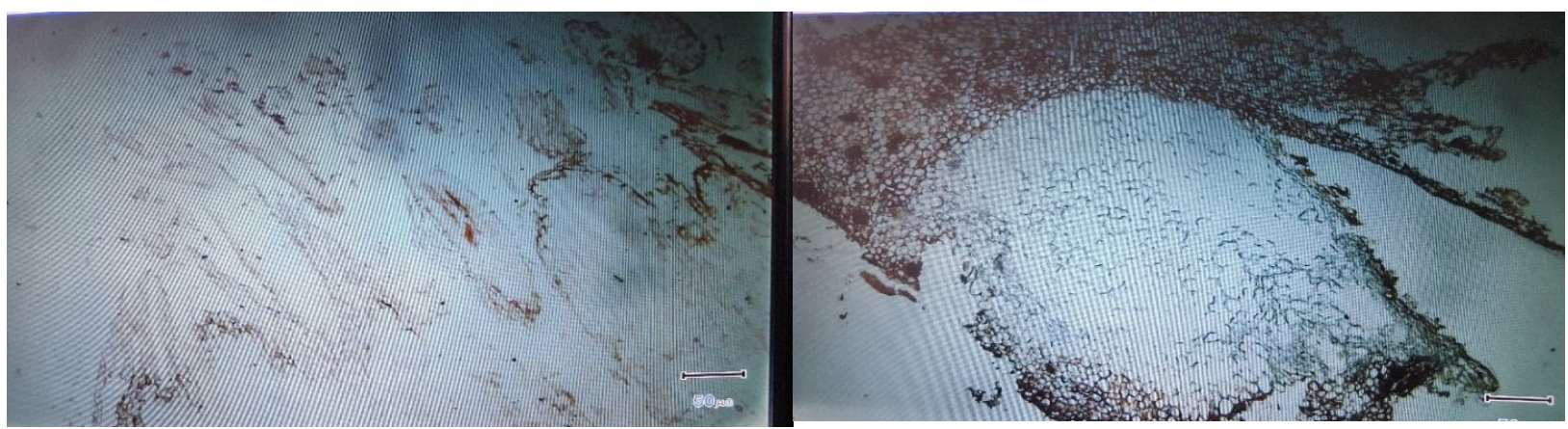

Gambar 4. Hasil anatomi kalus dengan eksplan apokol media WPM dengan penambahan 2.4-D.

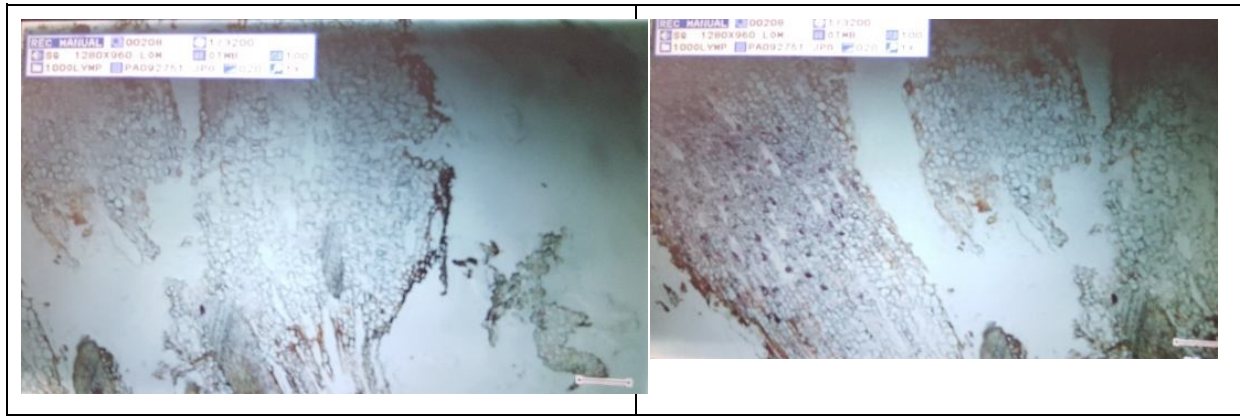

Gambar 5. Akhir tahap globuler dan awal diferensiasi dari eksplan apokol dengan media MS ditambah hormon BAP 1.5 ppm dan IBA 1.5 ppm. 


\section{PEMBAHASAN}

Secara konvensional, Dewi (2017) berhasil mengecambahkan biji aren hingga membentuk apokol. Secara in vitro juga sudah berhasil mengecambahkan biji aren hingga tumbuh membentuk apokol dengan media MS tanpa penambahan hormon.

Hasil penelitian menunjukkan bahwa eksplan apokol dari aren memiliki masa dorman, dimana setelah 6 minggu dikultur pada media MS atau WPM, belum menunjukkan pertumbuhan tunas maupun akar. Namun dengan penambahan 2.4-D, eksplan berhasil membentuk kalus yang bersifat kompak dan berwarna kecoklatan. Waryastuti et al., (2017) menyatakan bahwa induksi kalus merupakan tahapan penting dalam hibridisasi somatik tanaman. Pemberian 2.4-D 2 ppm pada media MS dapat menginduksi kalus secara cepat dan efisien walaupun tanpa BAP pada tanaman temulawak.

Benih aren dapat menumbuhkan apokol jika ditanam pada media yang cocok dengan perlakuan pemanasan terlebih dahulu sebelum disemaikan. Apokol tersebut dapat digunakan sebagai sumber eksplan secara aseptik. Terbentuknya tunas dan akar sangat bergantung pada fase pertumbuhan dan perkembangan tanaman yang dipengaruhi oleh hormon auksin sebagai hormon induksi akar dan sitokinin untuk induksi tunas. Arsyad (2013) berhasil melakukan teknik penyelamatan embrio agar mendapatkan bibit aren dalam waktu singkat dengan menggunakan media Y3 dan WPM. Penambahan hormon NAA 5 ppm dan BAP 5 ppm dapat menghasilkan jumlah planlet tertinggi dan berhasil diregenerasi melalui penyelamatan embrio dan aklimatisasi.
Wahyudi et al. (2013) berhasil me.nginduksi tunas aren secara in vitro dengan menggunakan hormon NAA 1 ppm.

Konsentrasi hormon dalam media berpengaruh terhadap pertumbuhan akar dan tunas eksplan. Hormon IBA sebanyak 1.5 ppm belum mampu menumbuhkan akar pada eksplan apokol aren. Kartina et al., (2011) berhasil menumbuhkan akar dari eksplan hipokotil dan epikotil aren yang dikultur pada media MS dengan tambahan IBA 2 ppm.

Embrio somatik tanaman mengalami beberapa fase dalam perkembangannya. Fase globuler, fase bentuk hati lalu menjadi fase torpedo. Pada pengamatan kalus dari apokol aren tampak mengalami akhir fase globuler dan mulai diferensiasi walaupun belum seragam dimana dinding sel mengalami penebalan. Kasi dan Sumaryono (2016) melaporkan bahwa embrio somatik tanaman sagu (Metroxylon sagu Rottb) pada inisiasi kultur tampak $61 \%$ embrio pada tahap globuler, $9 \%$ bentuk hati dan $30 \%$ pada tahap torpedo. Namun pada akhir pengamatan, diperoleh $56 \%$ embrio tetap pada fase globuler setelah 6 minggu kultur.

\section{KESIMPULAN DAN SARAN}

Media dan penambahan hormon pada media mempengaruhi pertumbuhan apokol. Penggunaan 2.4-D 4 ppm untuk induksi kalus dapat membantu keterbatasan jumlah apokol untuk perbanyakan tanaman. Perlu penelitian lebih lanjut untuk mencari hormon yang efektif mendorong pertumbuhan kalus menjadi tunas baru. 


\section{DAFTAR PUSTAKA}

Ajijah, N. 2016. Pengaruh komposisi media dasar dan jenis eksplan terhadap pembentukan embrio somatik kakao. J.TIDP 3(3): 127-134

Arsyad, M.A. 2013. Embryo rescue secara in vitro dan produksi bibit aren (Arenga pinnata MERR). Institut Pertanian Bogor, Tesis.

Brownleader, MD and P.M.Dey. 1997. Plant Biochemistry: Plant cell biotechnology. Academic Press Ltd.

Dewi, N.K.Y.T. 2017. Perbanyakan tanaman aren secara in vivo dan in vitro. Prodi Biologi, FMIPA, Unud. Skripsi

Effendi, D.S. 2010. Prospek pengembangan tanaman aren (Arenga pinnata Merr) mendukung kebutuhan bioetanol di Indonesia. Perspektif 9(1): 36-46.

Kartina, A.M., Nurmayulis dan Susiyanti. 2011. Pengaruh Indole Butiric Acid (IBA) terhadap pembentukan akar pada tanaman aren. J. Agrivigor 10(2):208-218.

Kasi, P.D dan Sumaryono. 2016 . Keragaman morfologi selama perkembangan embrio somatic sagu (Metroxylon sagu Rottb). E-Jurnal Menara Perkebunan 74(1): 43-51.

Pamungkas, T dan L. Haryjanto. 2016. Konservasi ex-situ Aren (Arenga pinnata MERR). Balai Besar Penelitian Bioteknologi dan Tanaman Hutan. Yogyakarta.

Ruslan, S.M., Baharuddin dan Taskirawati, I. 2018. Potensi dan pemanfaatan tanaman aren dengan pola agroforestry di Desa Palakka, Kecamatan Barru, Kabupaten Barru. Jurnal Perrenial 14(1): 24-27.

Wahyudi, E., Ernita dan Fathurrahman. 2013. Uji Konsentrasi Kinetin dan NAA terhadap multiplikasi embrio aren (Arenga pinnata) secara in vitro. $\mathrm{J}$.
Dinamika Pertanian XXVIII (1): 5162.

Waryastuti, D.E., L.Setyobudi dan T. Wardiyati. 2017. Pengaruh tingkat konsentrasi 2.4-D dan BAP pada media MS terhadap induksi kalus embriogenik temulawak (Curcuma xanthorrhiza Roxb). Jurnal Produksi Tanaman 5(1): 140-149. 